Abstracted/indexed in Academic Search Complete, Asia Journals Online, Bangladesh Journals Online, Biological Abstracts, BIOSIS Previews, CAB Abstracts, Current Abstracts, Directory of Open Access Journals, EMBASE/Excerpta Medica, Google Scholar, HINARI (WHO), International Pharmaceutical Abstracts, Open J-gate, Science Citation Index Expanded, SCOPUS and Social Sciences Citation Index;

ISSN: $1991-0088$

\title{
Serum iron and total iron binding capacity in severely malnourished children
}

\author{
Md. Atiar Rahman, M. A. Mannan and Md. Hamidur Rahman
}

Department of Pediatrics, Bangabandhu Sheikh Mujib Medical University, Shahbag, Dhaka, Bangladesh.

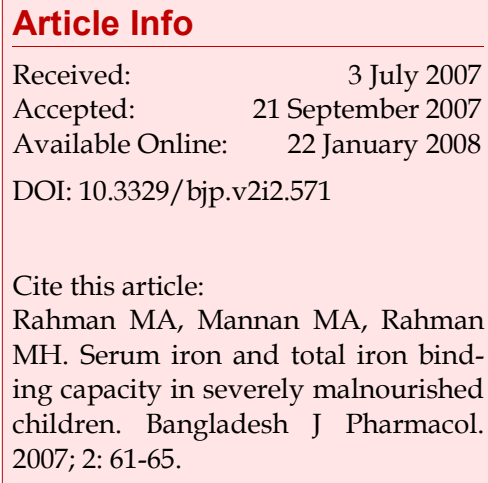

\begin{abstract}
Serum iron, total iron binding capacity and plasma protein of severely malnourished children of 12-59 months of age were compared with that of normal healthy children. Mean serum total protein and albumin level in normal children were $76.3 \pm 0.5,43.5 \pm 0.4 \mathrm{~g} / \mathrm{L}$ respectively which was significantly higher $(\mathrm{p}<0.05)$ than that of malnourished children $(64.4 \pm 0.6$, $30.2 \pm 0.5 \mathrm{~g} / \mathrm{L})$. But mean serum globulin level was $(34.2 \pm 0.3 \mathrm{~g} / \mathrm{L})$ higher in malnourished children than that of normal children $(32.8 \pm 0.5 \mathrm{~g} / \mathrm{L})$. The mean serum iron and transferrin saturation level were $(78.7 \pm 11.1 \mu \mathrm{g} / \mathrm{dL}, 23.4$ $\pm 2.0 \%)$ significantly high $(\mathrm{p}<0.001)$ in severely malnourished children than in normal children, whereas serum TIBC had no significant difference between these two groups.
\end{abstract}

\section{Introduction}

Protein-energy malnutrition (PEM) is one of the important causes of under 5 morbidity and mortality in our country. Each year 240,000 deaths among children under 5 years of age in Bangladesh can be attributed to malnutrition (more than 600/day). Two-thirds of under 5 children are malnourished in Bangladesh (Ministry of Health and Family Planning, 2003). The national child nutrition survey conducted in 2000 demonstrated that among the children of 6-71 months of age, almost $49 \%$ were found stunted and nearly $12 \%$ wasted and $52 \%$ were underweighted. It was found that among the South Asian countries (Surveyed from 1990-2000) prevalence of wasting were in Bangladesh 11.6\%, India $18 \%$, Pakistan 11\%, Nepal 11\%, Srilanka 14\%. Bhutan $4 \%$, Maldives 17\%, South Asia 18\%, and World 11\% (BBS and UNICEF, 2000).

Iron deficiency is a major contributor to the morbidity and mortality of children in Bangladesh. Nutritional surveillance project showed that $50 \%$ of all preschool children of Bangladesh are anemic and $34 \%$ of school children had low level of hemoglobin concentration
(IPHN/HKI, 2002). In case of severely malnourished wasted children, serum total protein and albumin are expected to be normal or reduced (Jelliffe, 1989; Suskind, 1990). Raised globulin level is also anticipated since malnutrition is commonly associated with infections (Huffman and Zahidul, 1983; Reeds and Laditan, 1976). Iron is an important integral component or essential cofactor for several metabolic processes which is deranged in PEM (Suskind, 1990).

Transferrin plays a key role in infection resistance during the period or physiological low concentration of immunoglobulin in growing children (Dallman, 1987; Sarma and Naidu, 1984). Nutritional deficiency adversely affects immune function and reduces the effectiveness of the host defence; thus inviting more infection and causing iron loss (Stekel, 1984; Dallman, 1987). Socio-economic factors also have an important role in iron deficiency especially in developing countries (Sarma and Naidu, 1984; Khanum, 1985). Nutritional anemia is one of the major causes of growth retardation, less physical activities and defect in cognitive function in children (Stekel, 1984; Hossain et al., 1983; Koerper et al., 1977). With this view the aims and objectives of this 
study was to observe level of serum total protein, serum albumin, serum globulin, serum iron, TIBC and transferrin in healthy and severely malnourished children in our country and to compare the result, among them.

\section{Materials and Methods}

This prospective study was carried out on 48 children with age range of 12-59 months. The places of study were the Department of Pediatrics, Dhaka Medical College Hospital, Bangabandhu Sheikh Mujib Medical University (BSMMU) and AD-DIN Hospital. The study period was from July 2003 to December 2004. Biochemical analysis was done at the Biochemistry Department of BSMMU. Children were broadly divided into two groups.

\section{Group I}

Consisted of 12 apparently healthy children whose weight for height Z-score (WHZ) >-2.

\section{Group II}

Consisted of 36 children whose WHZ were <-3. Detailed history including birth history, feeding history, past and present infection, treatment history and socio-economic status of both the groups were taken. While taking treatment history, special emphasis was given on the history of taking proteins, any vitamins, minerals and iron before their admission in the respective hospitals. For the purpose of taking history and other laboratory findings, pre-tested questionnaire was used by the investigator himself.

Thorough clinical examination was conducted in both groups.

\section{Selection criteria}

Severely malnourished children between 12-59 months of age were selected as the case. The apparently healthy male and female children aged 12-59 months of age with weight-for-height (WHZ) $>-2$ of the median NCHS/WHO reference values without any systemic disease were selected as control. Children between 1259 months of age having edematous malnutrition, anemia due to hemolytic anemia, leukemia, bleeding disorders and other malignant disease were excluded from the study.

\section{Sample collection, separation and preservation}

The patient and his/her attendants were given a detailed briefing about the purpose of the study. With all aseptic precautions $5 \mathrm{~mL}$ of venous blood was drawn randomly on day of admission before the treatment was started. Immediately after collection, blood was centrifuged at 3,000 rpm for $5 \mathrm{~min}$ on the same day. Supernatant clear serum was preserved at $-35^{\circ} \mathrm{C}$ in different vials till used for analysis.

\section{Analytical procedure}

Serum total protein, serum albumin, serum globulin, serum iron and TIBC were estimated by spectrophotometric technique.

Transferrin saturation $=$ Serum iron $x 100$

TIBC

\section{Statistical analysis}

All the values were expressed as mean \pm SEM; comparisons between two groups with the help of $p$ value. Statistical analysis was done by using SPSS 10.0. When $p$ value was less then $<0.05$ it was considered as significant and $<0.001$ was taken as highly significant.

\section{Results}

This prospective study included 48 children, among them 36 were severely malnourished and 12 were well nourished (normal children). After completion of data collection, all data were compiled, tabulated and analyzed according to objective of the study.

The characteristics of severely malnourished children are shown in Table I. Most of the cases were below 36 months of age group. Regarding sex distribution, in both sexes, below 36 months age group were most vulnerable. In male $10(62.5 \%)$ and in female $16(80 \%)$ cases were enrolled in this age group. The majority $(66.7 \%)$ belonged to parental monthly income group of Taka less than two thousand. The highest prevalence of severe malnourished children 20 (55.6\%) were in those families whose number of siblings were three to five. In present study low birth weight babies contributed to 30 $(83.3 \%)$ of study subject; on the other hand, $6(16.7 \%)$ had normal birth weight. So, highest prevalence of malnourished was noted among the low birth weight children.

Table I also shows the characteristics of normal children enrolled for the study. When age and sex of the normal children were considered, the majority were below 36 months age group in both sexes. Among normal children about $8(66.7 \%)$ were below 36 months age group, $4(33.3 \%)$ were male and $8(66.7 \%)$ were female. Of the normal children, $10(83.3 \%)$ were in those families whose number of sibling were one to three and their parental income per month more than three thousand Taka. This study also reflect that among the normal children $6(50 \%)$ had normal birth weight and 6 (50\%) had low birth weight.

Table II shows the mean serum total protein and albumin level in normal children were $76.3 \pm 0.5,43.5 \pm$ $0.4 \mathrm{~g} / \mathrm{L}$ respectively which was significantly higher $(\mathrm{p}<0.05)$ than malnourished children $(64.4 \pm 0.4,30.2 \pm$ 


\begin{tabular}{|c|c|c|c|c|c|}
\hline \multicolumn{6}{|c|}{ Table I } \\
\hline \multicolumn{6}{|c|}{ Characteristics of children } \\
\hline \multicolumn{3}{|c|}{ Severely malnourished children } & \multicolumn{3}{|c|}{ Normal children } \\
\hline \multirow[t]{2}{*}{ Age (months) } & & Frequency\% & Age (months) & & Frequency $\%$ \\
\hline & $\begin{array}{r}<36(\mathrm{n}=23) \\
36-59(\mathrm{n}=13)\end{array}$ & $\begin{array}{l}63.9 \\
36.1\end{array}$ & & $\begin{array}{r}<36(\mathrm{n}=8) \\
36-59(\mathrm{n}=4)\end{array}$ & $\begin{array}{l}66.7 \\
33.3\end{array}$ \\
\hline Sex & & & \multicolumn{3}{|l|}{ Sex } \\
\hline Male & $\begin{array}{l}<36(\mathrm{n}=10) \\
36-59(\mathrm{n}=6)\end{array}$ & $\begin{array}{l}62.5 \\
37.5\end{array}$ & Male & $\begin{array}{r}<36(\mathrm{n}=4) \\
36-59(\mathrm{n}=0)\end{array}$ & $\begin{array}{r}33.3 \\
0\end{array}$ \\
\hline Female & $\begin{array}{r}<36(\mathrm{n}=16) \\
36-59(\mathrm{n}=4)\end{array}$ & $\begin{array}{l}80 \\
20\end{array}$ & Female & $\begin{array}{r}<36(\mathrm{n}=8) \\
36-59(\mathrm{n}=0)\end{array}$ & $\begin{array}{r}66.7 \\
0\end{array}$ \\
\hline \multicolumn{3}{|c|}{ Socio-economic status } & \multicolumn{3}{|c|}{ Socio-economic status } \\
\hline \multirow{3}{*}{$\begin{array}{l}\text { Income per- } \\
\text { month taka }\end{array}$} & $<2000(\mathrm{n}=24)$ & 66.7 & \multirow{3}{*}{$\begin{array}{l}\text { Income per-month } \\
\text { taka }\end{array}$} & $<2000(\mathrm{n}=0)$ & 00 \\
\hline & $2000-3000(n=12)$ & 33.3 & & $2000-3000(n=4)$ & 33.3 \\
\hline & $>3000(\mathrm{n}=0)$ & 0 & & $>3000(\mathrm{n}=8)$ & 66.7 \\
\hline \multirow{3}{*}{$\begin{array}{l}\text { Number of sib- } \\
\text { ling }\end{array}$} & $<3(n=0)$ & & \multirow[t]{3}{*}{ Number of sibling } & $<3(n=10)$ & 83.3 \\
\hline & $3-5(n=20)$ & 55.6 & & $3-5(n=2)$ & 16.7 \\
\hline & $>5(n=16)$ & 44.5 & & $>5(\mathrm{n}=0)$ & 00 \\
\hline $\begin{array}{l}\text { Low birth weight } \\
(\mathrm{n}=30)\end{array}$ & & 83.4 & $\begin{array}{l}\text { Low birth weight } \\
(\mathrm{n}=6)\end{array}$ & & 50 \\
\hline $\begin{array}{l}\text { Normal birth } \\
\text { weight }(\mathrm{n}=6)\end{array}$ & & 16.7 & $\begin{array}{l}\text { Normal birth } \\
\text { weight }(\mathrm{n}=6)\end{array}$ & & 50 \\
\hline
\end{tabular}

Table II

Comparison of plasma protein profiles between normal and malnourished children

\begin{tabular}{|lcccc|}
\hline Types of subject & Number & $\begin{array}{c}\text { Serum total protein g/L } \\
\text { Mean } \pm \text { SE }\end{array}$ & $\begin{array}{c}\text { Serum albumin g/L } \\
\text { Mean } \pm \text { SE }\end{array}$ & $\begin{array}{c}\text { Serum globulin g/L } \\
\text { Mean } \pm \text { SE }\end{array}$ \\
\hline Normal children & 12 & $76.3 \pm 0.5^{\mathrm{a}}$ & $43.5 \pm 0.4^{\mathrm{a}}$ & $32.8 \pm 0.5$ \\
Malnourished children & 36 & $64.4 \pm 0.6$ & $30.2 \pm 0.5$ & $34.2 \pm 0.3^{\mathrm{a}}$ \\
\hline
\end{tabular}

ap $<0.05$ (Significant)

\section{Table III}

Comparison of serum iron, TIBC and transferrin saturation between normal and malnourished children

\begin{tabular}{|lcccc|}
\hline Types of subject & Number & $\begin{array}{c}\text { Serum iron }(\mathrm{mg} / \mathrm{dL}) \\
\text { Mean } \pm \text { SE }\end{array}$ & $\begin{array}{c}\text { TIBC }(\mathrm{mg} / \mathrm{dL}) \\
\text { Mean } \pm \text { SE }\end{array}$ & $\begin{array}{c}\text { Transferrin saturation } \% \\
\text { Mean } \pm \text { SE }\end{array}$ \\
\hline Normal children & 12 & $40.4 \pm 5.1$ & $374.8 \pm 56.1$ & $10.6 \pm 2.6$ \\
Malnourished children & 36 & $78.7 \pm 11.1 \mathrm{~b}$ & $342.1 \pm 24.6$ & $23.4 \pm 2.0 \mathrm{a}$ \\
\hline
\end{tabular}

ap $<0.05$ (Significant); $\mathrm{b} p<0.001$ (Highly significant)

$0.5 \mathrm{~g} / \mathrm{L})$. On the other hand, mean serum globulin level $(34.2 \pm 0.3 \mathrm{~g} / \mathrm{L})$ in malnourished children higher than in normal children $(32.8 \pm 0.5 \mathrm{~g} / \mathrm{L})$.

The values of serum iron, TIBC and transferrin saturation in malnourished and normal children are shown in Table III. The mean serum iron and transferrin saturation level were $(78.7 \pm 11.1 \mu \mathrm{g} / \mathrm{dL}, 23.4$ $\pm 2.0 \%)$ significantly high $(p<0.001)$ in malnourished children than in normal children whereas serum TIBC had no significant difference between these two groups.

\section{Discussion}

Malnutrition is one of the important causes of under 5 mortality and morbidity in our country. Two-third of under 5 children are malnourished (Ministry of Health 
and Family Planning, 2003). In Bangladesh 50\% of all preschool children are anemic and $34 \%$ of school children had low level of hemoglobin concentration (IPHN/HKI Nutritional Surveillance Project, Bull, 2002). Malnutrition associated with iron deficiency is more common in kwashiorkor but not in marasmic children (Jelliffe 1989; Suskind, 1990; Reddy and Srikantia, 1970).

In this study toddler, female children and children of low socioeconomic condition are the most vulnerable groups for malnutrition. This finding was also consistent with the other studies (Khanam, 1985; Begum and Islam, 1996).

The highest prevalence of severe malnutrition was noted in those families whose number of siblings was three to five and who had low birth weight. This finding was also observed by other authors (WHO, 1999; Khanam, 1985).

Serum total proteins and albumin levels were lower in the cases than that in the control group. This difference was proved statistically significant $(p<0.05)$. This well expected finding was very much similar to the observations of the previous study (Reeds and Laditan, 1976). The globulin level was higher in the cases than that of the control and this was statistically significant $(\mathrm{p}<0.01)$. The result is consistent with the findings of the previous study (Reeds and Laditan, 1976). This could be due to the increased incidences of malnutrition associated infection.

Iron status was significantly higher in cases than its level in the control group $(\mathrm{p}<0.001)$.

Accordingly total iron binding capacity (TIBC) level also supported better iron status in the cases. This did not show any statistical significance $(p=0.5)$. But transferrin saturation revealed significantly lower in the control group rather than in the cases $(\mathrm{p}<0.001)$.

Similar to the observation of this study iron deficiency was mentioned in association with kwashiorkor, but not with marasmus (Jelliffe 1989; Suskind 1990; Reddy and Srikantia, 1970).

Some dissimilarity was noted between the present study and the previous one done by Begum and Islam (1996). This could be due to the fact that age range was 3 months to 8 years and Gomez classification was taken in the previous study and here in this study only 12-59 months age group child were included and WHO classification was the basis of the categorization of the study.

In this study iron status was clearly compared between the control and the cases. Statistical analysis distinctly showed the lower iron status in the control group $(p<0.05)$. This observation and statistically acceptable inferences are explainable as iron deficiency is very common in our community regardless of the status of PEM (HKI, Nutritional Surveillance Project, Bull 10, 2002; Dallman, 1987; Stekel, 1984; Sarma and Naidu, 1984). Also the severely malnourished children admitted in the tertiary level hospitals are usually seen by some of the doctors and treated by certain vitamins and supplements which might have affected the iron profile of the cases in the current study.

\section{Conclusion}

Severely wasted malnourished children, serum total protein and albumin levels were lower, but globulin level was higher. On the other hand, iron and TIBC levels were normal.

\section{Acknowledgement}

We are grateful to Prof. Mir Misbahuddin of Bangabandhu Sheikh Mujib Medical University, Dhaka, for his constructive criticism of this work.

\section{References}

Bangladesh Bureau of Statistics (BBS) and United Nations International Children Emergency Fund (UNICEF). Child nutrition survey in Bangladesh. 2000, p 41.

Begum T, Islam MN. Study on serum iron, total iron binding capacity in hospitalized PEM children. Bangladesh J Child Health. 1996; 20: 77-82.

Dallman PR. Iron deficiency and the immune response. Am J Clin Nutr. 1987; 46: 329-34.

Haffman SL, Zahidul AA. Preschool child malnutrition in Bangladesh; Causes and intervention. Bangladesh Pediatr. 1983; 7: 98-99.

Hossain M, Kawser CA, Talukder MQ-K. Changing prognosis in severe protein energy malnutrition. Bangladesh Pediatr. 1983; 7 : 15-17.

Institute of Public Health Nutrition (IPHN)/Helen Keller International (HKI), Dhaka; Anemia is a severe public health problem in pre-school children and pregnant woman in rural Bangladesh. Nutritional Surveillance Project Bulletin10. 2002, pp 1-2.

Jelliffe DB, Jelliffe EFP. Community nutrition assessment. Oxford, Oxford University Press, 1989, pp 39-48, 273-351.

Khanum S. Factors contributing to protein energy malnutrition in urban Dhaka. Bangladesh J Child Health 1985; 9: 80-89.

Koerper MA, Dallman PR. Calif SF. Serum iron concentration and transferrin saturation in the diagnosis of iron deficiency in children. Normal developmental changes. J Pediatr. 1977; 6: 870-74.

Ministry of Health and Family Welfare. Child health situation 
in Bangladesh: Technical guidelines for child health intervention in Bangladesh. 2003, pp 1-2.

Reddy V, Srikantia SG. Anemia in kwashiorkor. Indian J Med Res. 1970; 58: 645-50.

Reeds PJ, Laditan AAO. Serum albumin and transferrin in protein-energy malnutrition. Br J Nutr. 1976; 36: 255-63.

Sarma KVR, Naidu AN. Anemia in children. Indian Pediatr. 1984; 21: 295-98.
Stekel A. Iron nutrition in infancy and childhood. New York, Raven Press, 1984, pp 1-7.

Suskind RM, Suskind LL. The malnourished child, Nestle nutrition workshop series- 19. New York, Raven Press, 1990, pp 23-72.

World Health Organization. Management of severe malnutrition. A manual for physicians and other senior health workers. Geneva, World Health Organization, 1999, p 4 . 